\title{
CHEMICAL, PHYSICAL AND MICROBIOLOGICAL STUDIES ON SOME EGYPTIAN CULTIVARS OF ONION
}

\author{
(Received:18.10.2007) \\ By \\ M. M. Abd El-Magied, A.M. Alian, A.M. Khourshed*and L. A. Mohamed* \\ Department of Food Technology, Faculty of Agriculture, Cairo University, Giza, Egypt. \\ * Food Technology Research Institute, Agricultural Research Center, Giza ,Egypt.
}

\begin{abstract}
Chemical, physical and microbiological studies have been carried out on three onion cultivars Giza 6, Giza 20 and Beheri which are widely cultivated locally. These included different pre-drying treatment ( $1.0 \%$ citric acid $+0.5 \% \mathrm{NaCL} ; 0.2 \% \mathrm{CaCL}_{2} ; 1.0 \%$ ethyl alcohol; $\left.2.0 \% \mathrm{NaCL}\right)$ and dehydration methods using freeze-drying, conventional drying and solar drying. Studies were also extended to investigate the effect of suitable packages for the dehydrated products through their storage for 9 months. Results indicated that, the moisture content of fresh onion was found to be 81.1, 82.8 and 84.9\% for onion cvs. Giza 6, Giza 20 and Beheri, respectively, while it decreased to be only 1.45 to $1.92 \%$ by using freeze drying, 1.89 to $5.90 \%$ by using conventional drying and 2.70 to $5.71 \%$ by using solar drying. Fresh onion had higher amount of total pungency (10.5 and 13.3 umol pyruvate/g fresh onion), while it decreased as a result of volatilization during dehydration to be 5.2-9.8 umol pyruvate/g. Beheri onion samples contained the highest amount of total pungency as compared with Giza 6 or Giza 20.. The laminates of "PAPEP" were considered to be the best packaging material as compared with (PE) or (PP). The stored dried onion samples of all cultivars had less amounts of moisture at the end of 9 months storage. The dried samples packaged under vacuum had slightly higher amounts of sugars acid content than those packed under atmospheric pressure. The pungency of packed onion into PAPEP either under vacuum or under atmospheric pressure recorded the highest values throughout storage periods, however, it was also slightly decreased with the increasing of storage period. The estimated Hunter lab color differences (L,a and b) of fresh and the corresponding dried onion cultivars could reflect the variations between fresh and dried samples. The least color index (O.D) was found with freeze dried onion samples. Freeze dried onion samples showed the highest values of rehydration ratio followed by those dried by solar technique and conventional oven. The changes into Hunter lab color difference during storage of dried samples for 9 months in different packaging materials were slightly increased as the storage period extended. Beheri gave the darkest dried onion sample, hence it recorded the highest value of O.D (color index). Onion samples pretreated with $1.0 \%$ ethyl alcohol were lighter than the others. Results showed a slight decrease in re-hydration ratio of onion cultivars by increasing storage period which packaged into different packaging materials.

Effect of dehydration techniques indicated that solar drying had the highest amounts of total count, followed by the conventional drying method and then freeze dried method. Onion samples treated with $2.0 \%$ table salt contained the lowest microbial load, followed by those treated with $1.0 \%$ ethyl alcohol and citric acid $1.0 \%+\mathrm{Nacl} 0.5 \%$, as compared with the control samples. The total count was nearly stable during 9 months storage in the different packaging materials.
\end{abstract}

Key words: chemical, cultivars, onion, package, physical, storage.

\section{INTRODUCTION}

Onion (Allium cepa L.) is considered one of the major crops; it is used on large scale in food preparation and for exportation. It plays a good role in Egyptian national income. It is an important crop not only as a condiment in food, but also for its biological effect and its antimicrobial activity against wide range of microorganisms (Mesbah and Abu El-Ela, 1991). The local fresh onion yield of about 52 thousand feddans was found to be 1.3 million tons in 1995 . Out of this amount 6 thousand tons of onion were dehydrated. Egypt exported 5 and 8 thousand tons of dehydrated onion in 1997 and 1998, respectively.

Fresh onion had $84.0 \%$ moisture, $2.0 \%$ crude protein, $0.8 \%$ total lipids, $0.7 \%$ crude fiber and $0.84 \%$ total ash (Youssef et al., 1981). They also 
determined the contents of minerals $(\mathrm{mg} / 100 \mathrm{~g}$ dry wt.), Phosphorous 375; Sulfur 637; Calcium 295; Manganese 26.5; Copper 1.24; Iron 16.8 and Zinc 6.8. Results obtained by Hegazy et al. (1994) expressed in dry wt. that the basics were (\%) 82.1 moisture, 9.8 total protein; 4.48 fat; 4.6 fiber; 3.17 ash; 68.25 total sugars; 27.61 reducing sugars and 40.64 non reducing sugars of fresh onion. After dehydration in an oven under aeration conditions these reached about $5.69 ; 9.23 ; 4.356 ; 4.82 ; 3.57$; $67.43 ; 29.86$ and $37.57 \%$ respectively (on dry wt. basis). Onion pungency develops when the enzyme allinase hydrolyzes the flavor precursors S- alkenyl L- cysteine sulfoxides during tissue maceration. The reaction products are pyruvate, ammonia, and many volatile sulfur compounds characteristics of onion flavor and aroma (Lancaster and Boland, 1990).

The pyrurate content is considered as an indicator of flavor intensity of onion. The characteristic flavor (pungency) or aroma of onion is due to the volatile matter consisting mainly of sulphur compounds and based on the reaction that on disintegration of onion tissue, two molecules of flavor precurson (S-alkyl- L - cysteine sulphoxide) undergo hydrolysis, yielding two molecules of pyruvate and one molecule of thiolsulphinate (Mazza and Le-Maguer, 1980). Moreover, Da -Mota and Palau (1999) and Adam et al.(2000) reported that the pyruvate content of garlic and onions during drying are mainly influenced by the drying temperature and time. Loss in pungency is strongly affected by water activity during storage as stated by Samaniego et al. (1991) and Kaymak - Ertekin and Gedik (2005)

Shekib et al.(1986); Rania et al.(1988) and Sharma and Niranvk (1991) found that dehydration reduced pungency and ascorbic acid levels. Shekib et al., (1986) determined such content in both fresh and dehydrated onion samples of both onion cultivars Giza 6 and Beheri as a measure of odor strength. It was 7.23 and 9.22 umol/g (dry basis) in the fresh onion and it dropped to 2.94 and 3.01 , and 3.5 and $3.88 \mathrm{umol} / \mathrm{g}$ for its flakes and powder prepared from onion cultivars Giza 6 and Beheri, respectively.

One of the most trouble in irreversible changes that accompany dehydration of food products is non enzymatic browning, which leads to loss of acceptable color, development of off flavor and loss of nutritive value. Samaniego et al., (1991) studied browning in commercially dehydrated onion flakes at ambient to nearambient temperature $\left(20-40^{\circ} \mathrm{C}\right)$ and reported that the change in color of the product was due to a non-enzymatic browning mechanism. Sharma and
Nath (1991) reported that browning, discoloration, loss of pungency and poor rehydration are the major problems of dehydrated onions. Saleh and El-Sherbeiny (1994) reported that onion was dehydrated in ventilated oven at $55^{\circ} \mathrm{C}$ for $15 \mathrm{hrs}$. to improve the quality attributes during packaging and subsequent storage for 3 months at ambient temperatures.

The non enzymatic browning reaction, which consists of the interaction of aldehyde, ketones and reducing sugars with amino compounds such as amino acids and proteins (Proudlove, 1989) is induced by the drying process and leads to loss of acceptable colour, the development of off-flavour and loss of protein biological value (Krokida and Maroulis (1999) and Ibarz, et al. (2000) and Kaymak- Ertekin and Gedik, (2005).

Powar et al. (1988) revealed that reducing and total sugars of white onion flakes (solar, air dried) were increased during storage period, as well as ascorbic acid retained slightly less of solar dried onion than mechanically air-dried. Meanwhile Saleh and El-Sherbeiny (1994) packed the dried sliced onions in dense polyethylene and sealed pouches under vacuum. They found that the packed dried onions could be stored at ambient temperature for 3 months. Additionally, during storage, reducing sugar, total sugar, vit. $\mathrm{C}$ and free amino nitrogen decreased in both onion cvs. Beheri and Seidi. Also, percent decrement was greater in samples steeped in water than those steeped in $1.0 \%$ ethanol, on contrary, color density increased in both cultivars. The main purpose of drying foods is to lower their moisture content to a particular level that will exclude the growth of microorganisms. The lower water activity of food, the less probable that microorganisms will grow (Johan and lovis, 1980). One of the food industries most important targets is to maintain high microbiological quality standards for its finished products (Bolliger et al., 1994).

The objectives of this study were to find out suitable methods for producing a dehydrated product for onion to prolong its shelf life by using suitable pretreatments before dehydration to avoid discoloration. Also proper packaging materials were used during storage. The quality of the dehydrated product was evaluated chemically, physically and microbiologically.

\section{MATERIALS AND METHODS}

2.1. Materials:

Onion (Allium cepa L.) cultivars used in this investigation included onion cvs. Giza 6, Giza 20 and Beheri obtained from Crops Research Institute, Agricultural Research Center, Ministry of Agriculture. 


\subsection{Methods}

\subsubsection{Dehydration process:}

Onion samples were separately peeled, washed, trimmed and manually cut into $2 \mathrm{~mm}$ thick rings. Samples of onions were subjected to some pretreatments before drying by freezedrying, conventional oven drying, and solar drying. Fig.(1) illustrates the diagram of pretreatment and dehydration methods.

\subsubsection{Physicochemical characteristics}

Moisture, for the raw and the processed materials was determined according to the method described in A.O.A.C (1990). The rehydration ratio was evaluated using the method of (Ranganna, 1979). The total sugars were determined as described by Smogyi (1952). Onion pungency was determined as pyruvate according to the methods of (Schimmer and Weston 1961) and (Wall and Corgan 1992). Color of onions product was measured with a Hunter Lab-ColorDifference meter $\mathrm{D}_{25.2}$ Model $\mathrm{D}_{25}$ optical sensor (Hunter Associates Laboratory).

\subsubsection{Microbiological essaay}

Total bacterial count was determined by using the plate count agar (Nutrient agar medium) as described by Julseth and Deible (1974). The plates were incubated at $30^{\circ} \mathrm{C}$ for 24 to $48 \mathrm{hrs}$. Yeast and fungal count was determined by the same procedure, but, Sabauroud agar medium was used. Plates were incubated at $28^{\circ} \mathrm{C}$ for 24 to $48 \mathrm{hrs}$.

\section{RESULTS AND DISCUSSION}

The moisture content of the three onion cultivars Giza6, Giza 20, and Beheri dehydrated and packed into different packaging materials, had no noticeable changes for each treatment separately during storage for 9 months at room temperature as shown in Table(1). Moreover, the lowest moisture content could be observed for the freeze dried samples. The control sample of solar dried onions had lower moisture content than the corresponding samples of the conventional oven dried onion. However, variations could be seen among the other pre-drying treatments. Also, packing at atmospheric pressure had slightly higher amounts of moisture than those packed under vacuum.

In this concept, Sharma and Nath (1991) recommended that rings of onion should be dehydrated to about $1.0 \%$ moisture and stored at $\mathrm{RH}$ (relative humidity) of $\leq 43.9 \%$ for safe storage. Meanwhile, Hegazy et al. (1994) suggested that, onion rings could be dehydrated up to $5.5 \%$ moisture content.

Concerning the effect of storage on the total sugars of different dehydrated onion cultivars, results in Table (2) show that, after 9 months of storage, the dried onion had less amount of total sugars as compared with the corresponding control sample before storage. In this concept, the dried onion samples are in accordence with their contents of total sugar in accordance to the dried method itself. So, freeze dried onion samples recorded the highest value of total sugars. Moreover, the pre-drying treatments had no noticeable effect on total sugars, with the exception of those samples treated with $1.0 \%$ ethanol, which had the lowest amount of total sugars. This could be contributed to the solubility of sugars through ethanol. Moreover, the packing materials PAPEP maintain the percentage of total sugars as the original content of the control sample through 9 months storage at ambient temperature. Also, the stored dried onion samples packed with P.E. had less percentage of sugars than those packed with P.P., which could be attributed to the higher permeability of P.E. than P.P and contributed to some oxidation of sugars and subsequently to this decrement. Our results are in accordance with those reported by Saleh and El-Sherbieny (1994) who observed gradual decrement in the total sugars, regarding to various storage periods and treatments for dehydrated onion cultivars Seidi and Beheiri. In addition, storage at high temperature in the range of $5^{\circ} \mathrm{C}$ to $40^{\circ} \mathrm{C}$ decreased the sugar content (Yamaguchi et al., 1982).

The fresh onion had higher amounts of total pungency (as pyruvate umol/g dry wt) comparing with the different dehydrated samples (Table 3). Onion "Beheri" contained the highest amount of total pungency as compared with onion "Giza 6", or" Giza 20". Among the dehydration technique, the results show that, freeze drying could protect the pungency of onion. In addition, the different pre-drying treatments for onions before drying had no effect on their pungency. However, samples pretreated with $1.0 \%$ ethanol caused some decrement in pyruvic acid for the three cultivars, which ascribed to the leaching process and not to specific enzymes as reported by Saleh and El. Sherbieny (1994). On the other hand the effect of packaging materials as well as storage at room temperature for 9 months on the total pungency content of the dehydrated sliced onion of the three cultivars show that, the pungency of packed onion into PAPEP either under vacuum or under atmospheric pressure recorded the highest values throughout storage periods. Moreover, onion samples packed into P.E or P.P had almost the same pungency. On the other hand, the pungency of the dehydrated onion was slightly decreased with the increasing of storage periods. This phenomenon could be observed for the three onion 


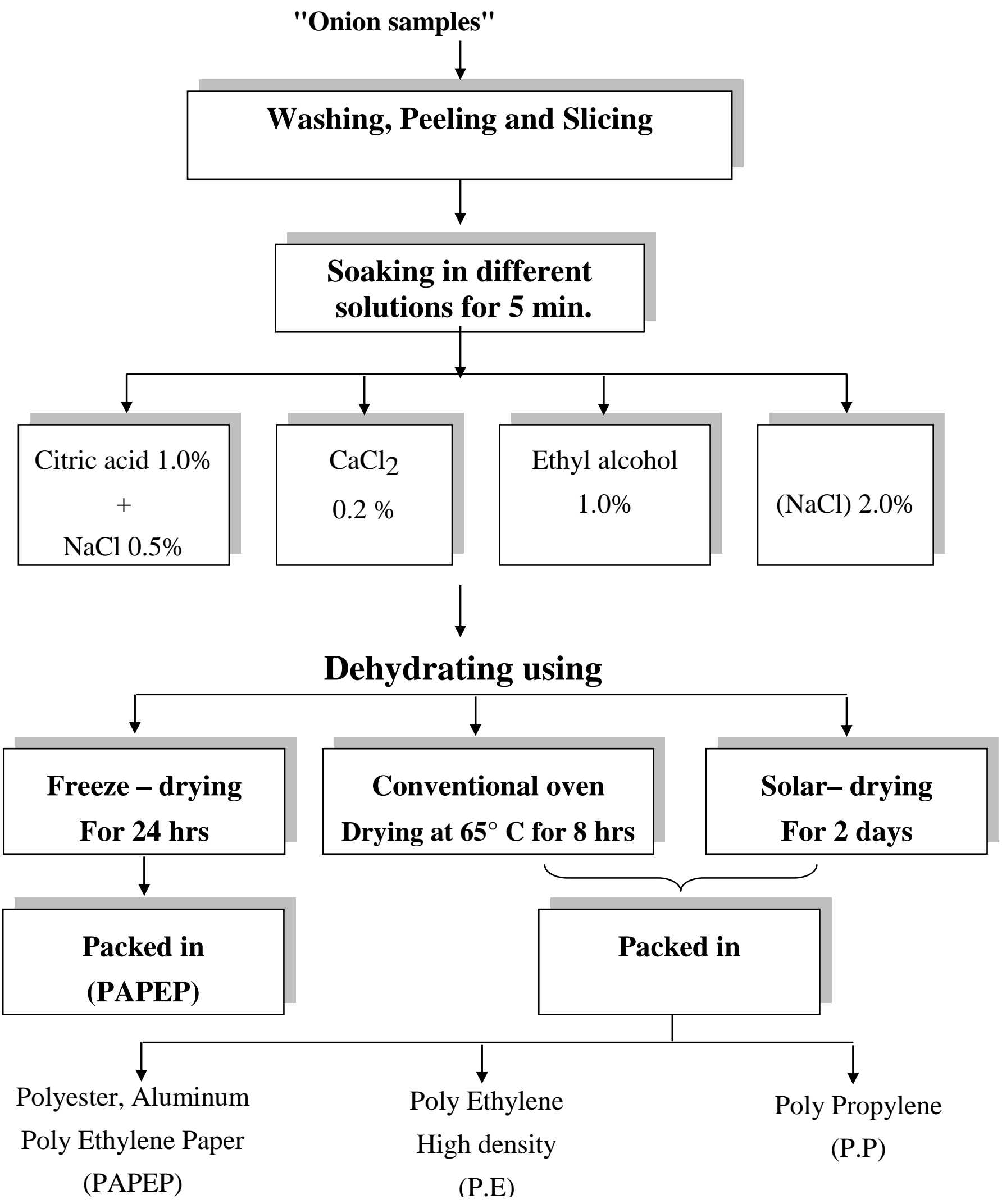

Fig.(1): Diagram of dehydration methods of onion samples. 


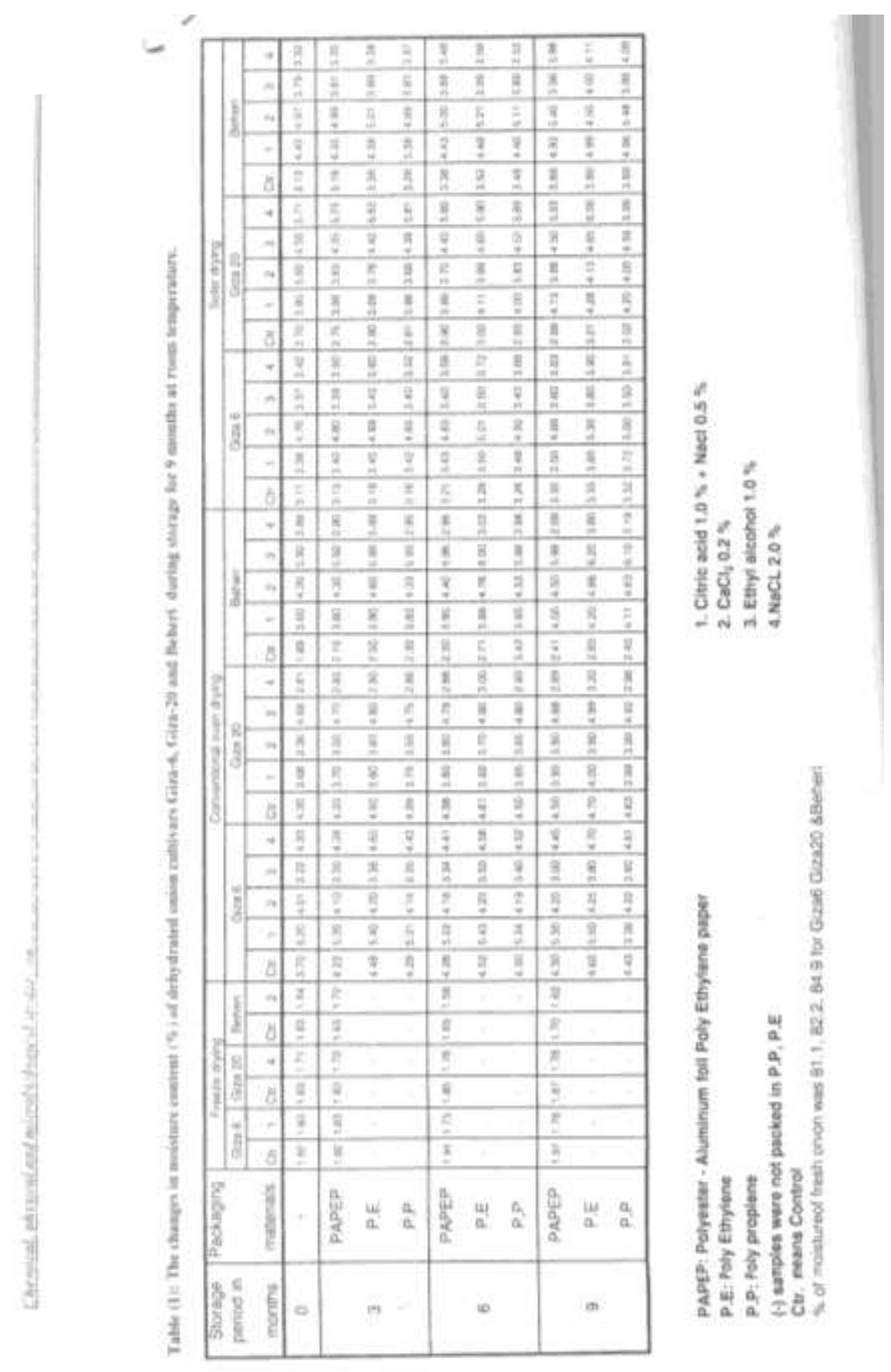




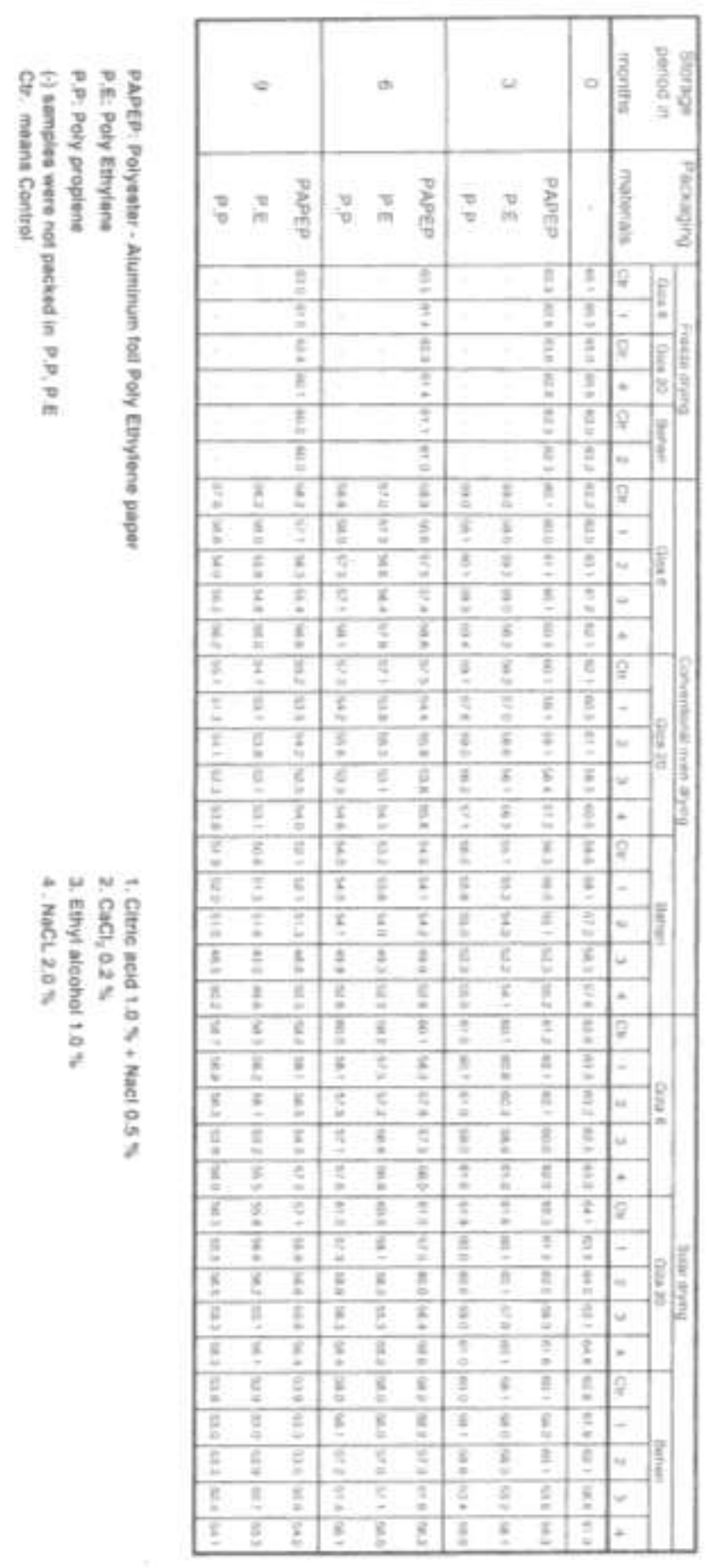




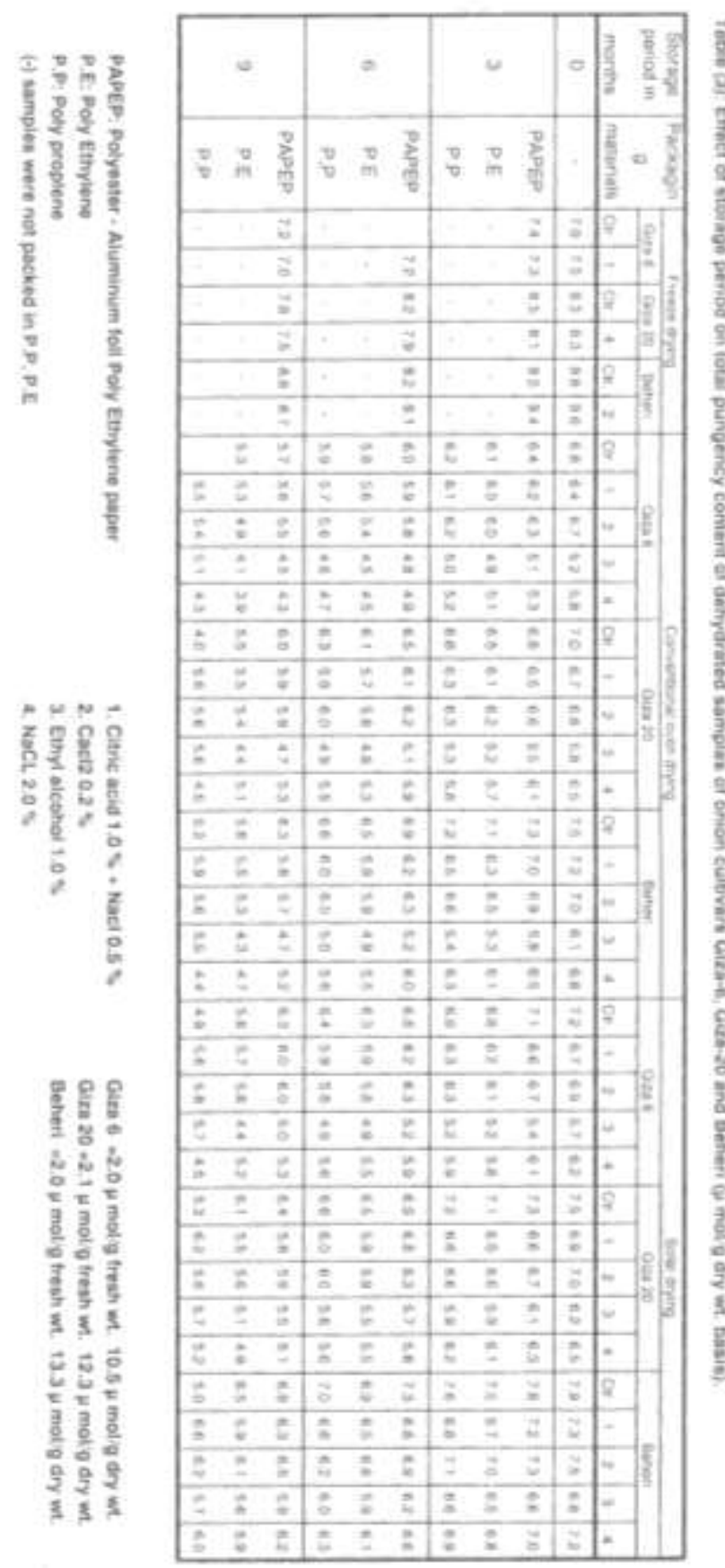


cultivars under investigation. These results agree with those reported by Peleg et al.,(1970) who stated that the pungency of dehydrated onion decreased gradually with the prolonged storage.

Concerning the rehydration ratio, the results in Table (4) show that the rehydration ratio of the control sample of freeze dried onion was higher than the corresponding controls of conventional or solar dried onion. In this concern, onion dried by solar drying had higher values of rehydration ratio than that dried by the conventional drying. This phenomenon could be seen for the three onion cultivars Gize 6, Giza 20 and Beheri. However, onion "Beheri" and "Giza 20" had slightly higher amounts of dehydration ratio than "Giza 6". Moreover, the pre-treatments for onion before drying had also some effect on the rehydration ratio. In this concept, onion samples treated with $2 \% \mathrm{NaCl}$ had the highest values of rehydration ratio. On the opposite side, onion samples treated with $0.2 \% \mathrm{CaCl}_{2}$ recorded the lowest values of rehydration ratio, which could be attributed to the hardness of the resultant samples and subsequently the capability for water sorption was less. It could be also concluded from the results that storage time up to 6 months had slight effect on the rehydration ratio of all the tested samples. This could be attributed to the effect of good packaging materials as well as good storage conditions. However, 9 months storage, the effect was clearer and the rehydration ratio decreased. Present results are in accordance with those reported by Maini et al., (1984) and Sharma and Nath (1991) who reported that the reconstitution ratio of dried onion was variable and attributed to the cultivars as well as storage.

Regarding the color measurement by Hunter lab $L$, $a$ and $b$ values for the fresh as well as the dried samples of different onion cultivars Giza 6, "Giza 20" and Beheri, results in Tables (5-7) show the differentiation among the fresh samples and subsequently the corresponding dried samples. In this concept onion "Beheri" had the lowest "L" values. The highest values of "a" indicated the darkness of the sample, which was plotted for the onion "Beheri" samples. On the contrary "Giza 6". and "Giza 20" recorded the highest value of "a" however, the highest values of " $b$ " were belonging to them. In addition, the pre-drying treatments did not affect the color measurements, but the dehydration process had some effect on the dried samples. Freeze dried onion had almost the same values of $\mathrm{L}, \mathrm{a}$ and $\mathrm{b}$ as the corresponding fresh samples of the three cultivars. So, it could be concluded that, the freeze drying technique could keep the good quality of dried onion followed by solar drying method. These results agree with those reported by Park and Lee (1994). Moreover, results in Tables (5-7) reflect color changes during storage for 9 months at room temperature for the three dehydrated onion cultivars. In this occasion onion "Beheri" was darker than "Giza 6" or "Giza 20". "Beheri" had low value of "L" lightness" and high value of "a" redness", meanwhile, the "b" value was in low marks which reflect the darkness of "Beheri" than the other two cultivars.

The microbiological studies on different cultivars of onions either fresh or stored dried in different packaging materials are shown in Tables $(8,9)$

Concerning the total plate count of fresh and dried onion cultivars, results in Table (8) show that, the fresh onion samples had the highest amounts of total count which recorded $137 \times 10^{3}$, $192 \times 10^{3}$ and 132 (cfu $\times 10^{3} / \mathrm{g}$ fresh sample) for onion "Giza 6", "Giza 20" and "Beheri", respectively. On the other hand, the dried onion samples had less amount of total count than the corresponding samples.

Among the dried onion samples, dried onion by solar drying had the highest amounts of total count, followed by conventional drying method and then freeze dried method which recorded the lowest score of total count.

Regarding the pre-drying treatments, results in Table (8) reveal that the onion samples treated with $2 \% \mathrm{NaCl}$ contained the lowest microbial load. Also, onion samples treated with $1.0 \%$ alcohol or $1.0 \%$ citric acid plus, $0.5 \%$ had also low microbial load as compared with the control samples or treated onion with $0.29 \% \mathrm{CaCl}_{2}$.

Data show clearly that, the total count was almost stable during 9 months storage in different packaging materials. Moreover, onion packed into PAPEP packing material had lower total count than those packed into P.E. or P.P. either at atmospheric pressure or under vacuum. In this concept Banwart (1979) reported that, the microbial counts of dried vegetables ranged from negligible number to millions per gram. He also reported that, the plate count of dried vegetables is usually $10^{3} / \mathrm{g}$ or less. On the other hand, Firstenberg et al., (1974), showed that the pretreating of raw onion in a $2-4 \%$ salt brine prior dehydration reduced microbial numbers in final products Additionally, Saleh and El-Sherbieny (1994) reported that, the drying process of sliced onions, caused decreasing pattern of their total counts. Concerning the total yeast and mould counts, the results in Table (9) reveal that the three cultivars of fresh onion had $22 \times 10^{3}, 28 \times 10^{3}$ and $23 \times 10^{3}$ (mould and yeast/lg fresh sample) for onion cvs. Giza 6, Giza 20 and Beheri, respectively. 

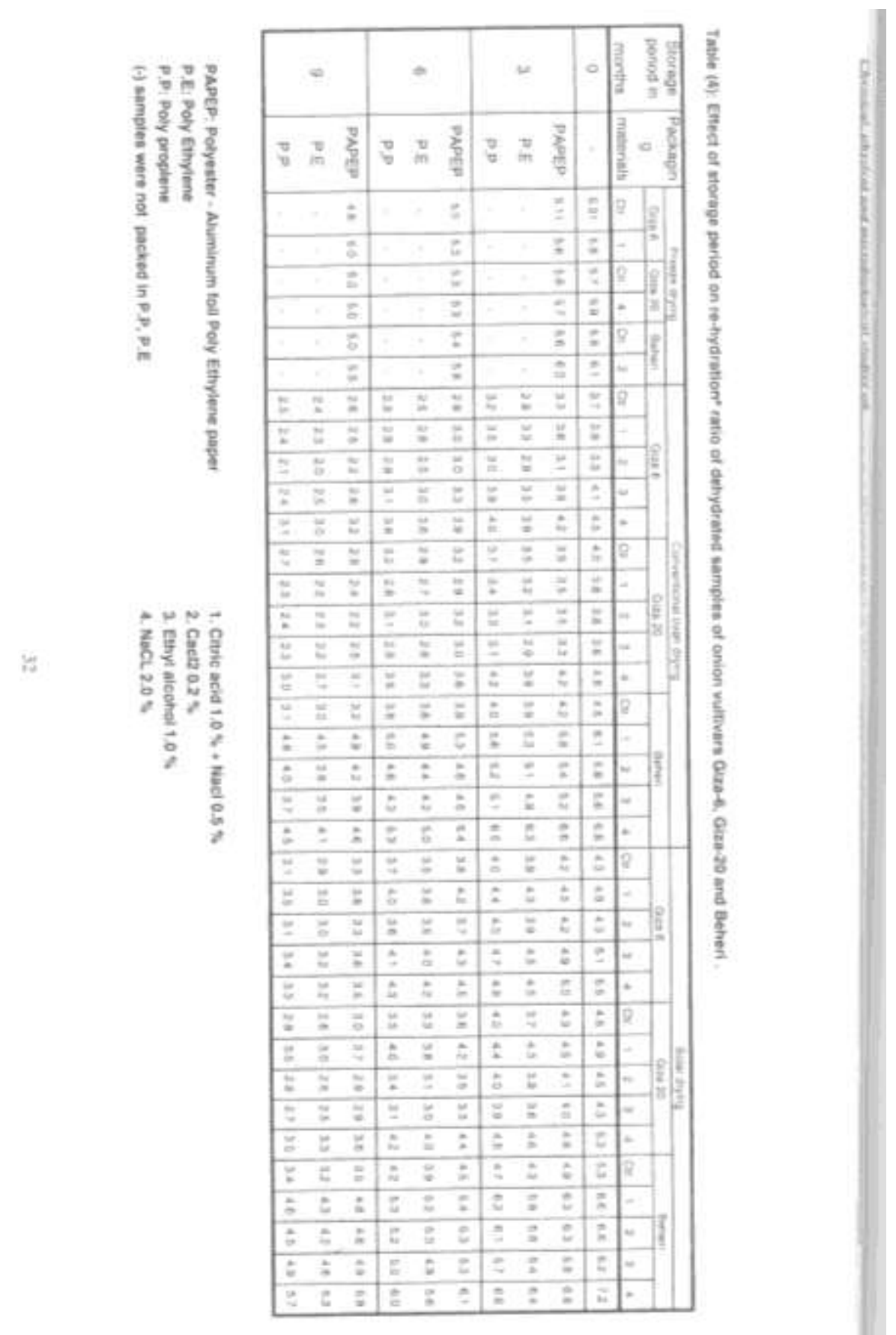


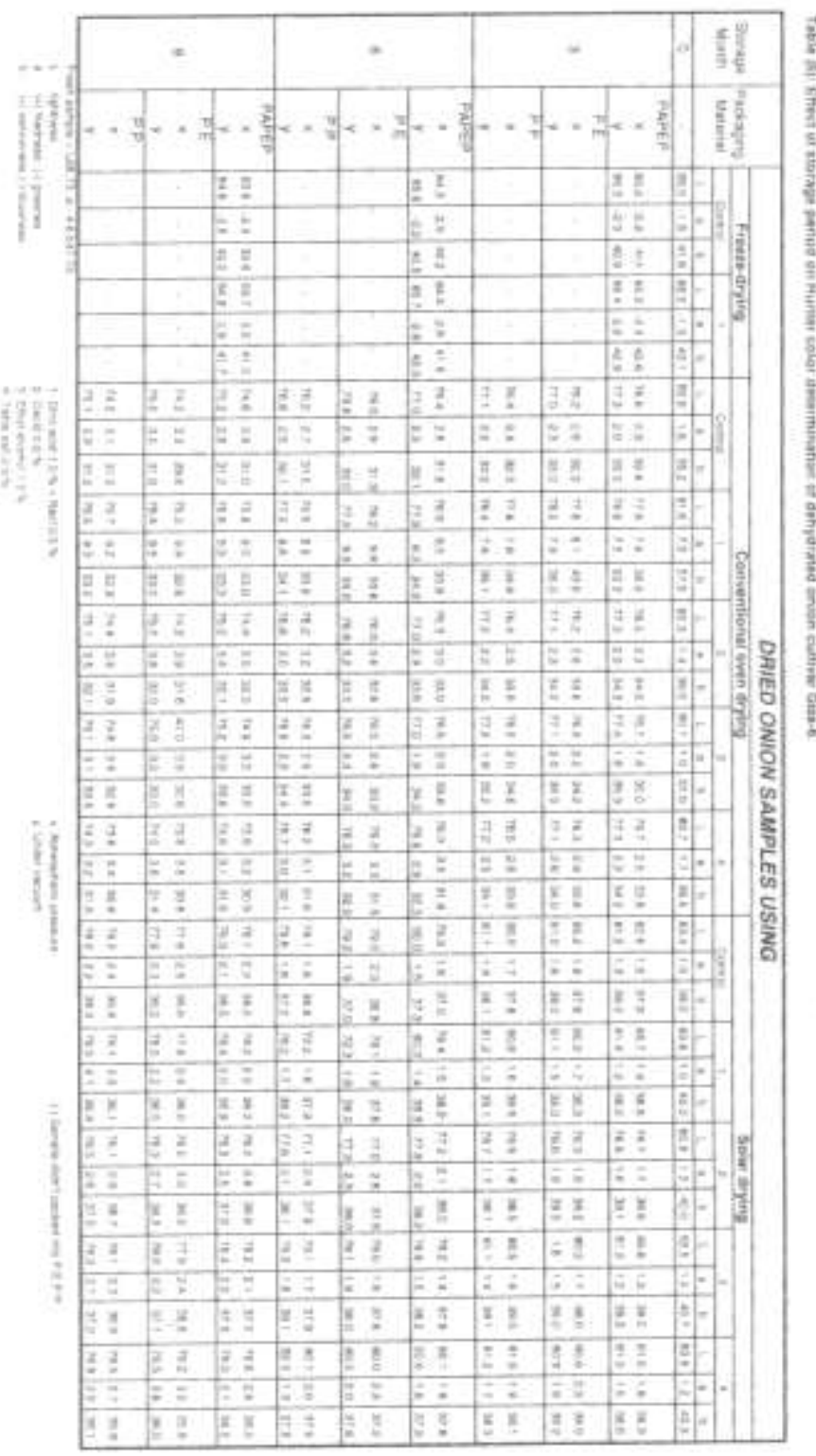



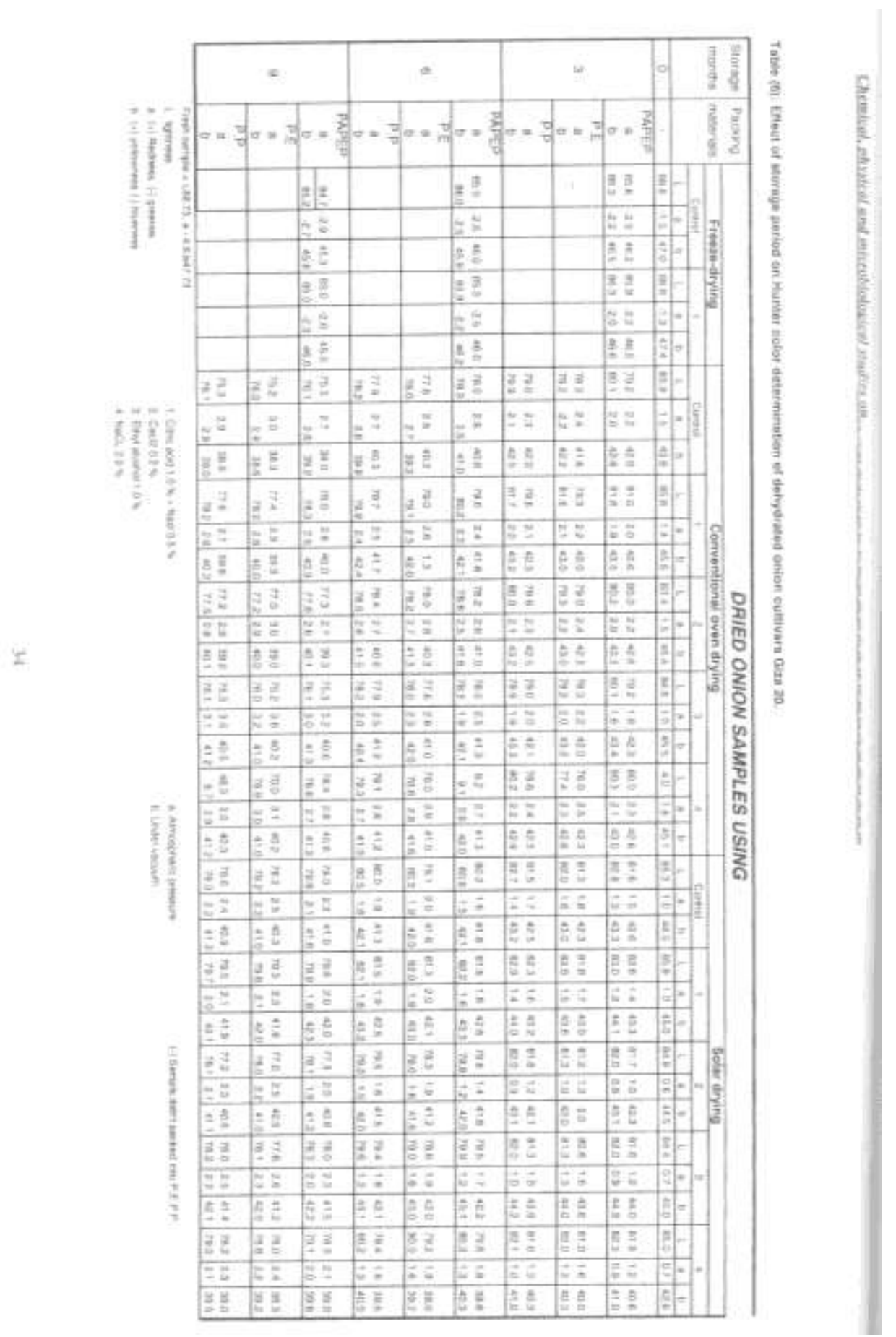


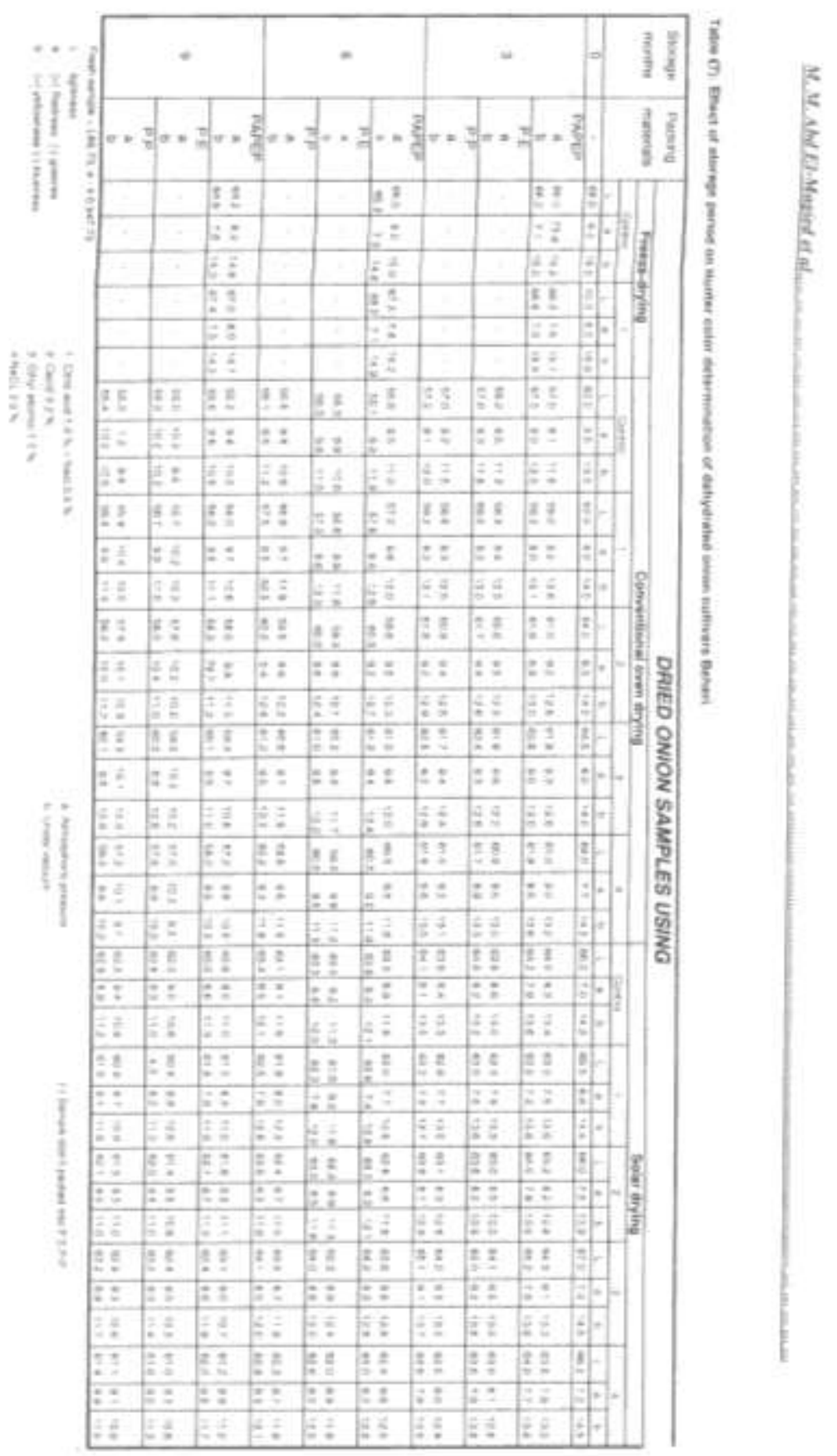




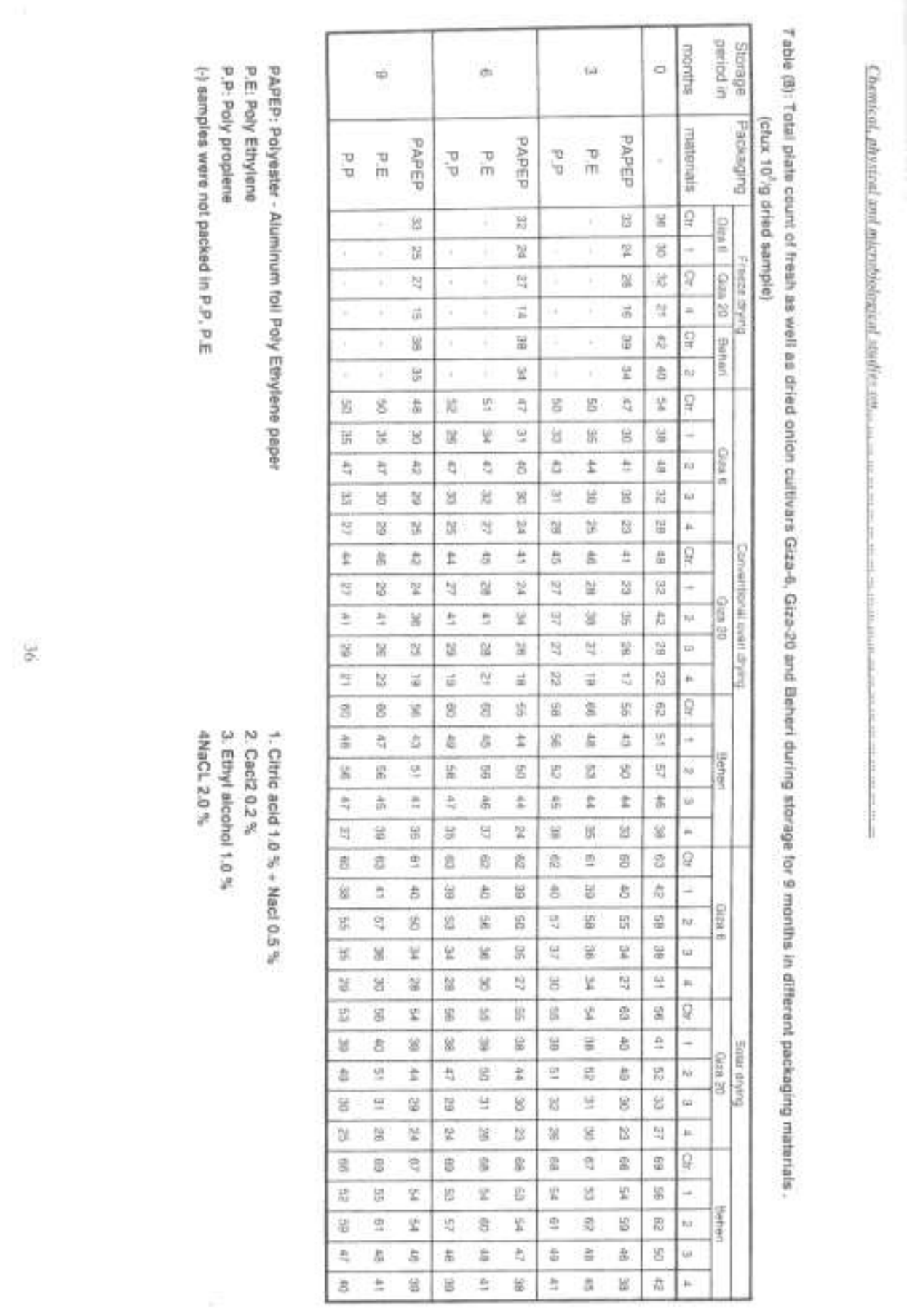




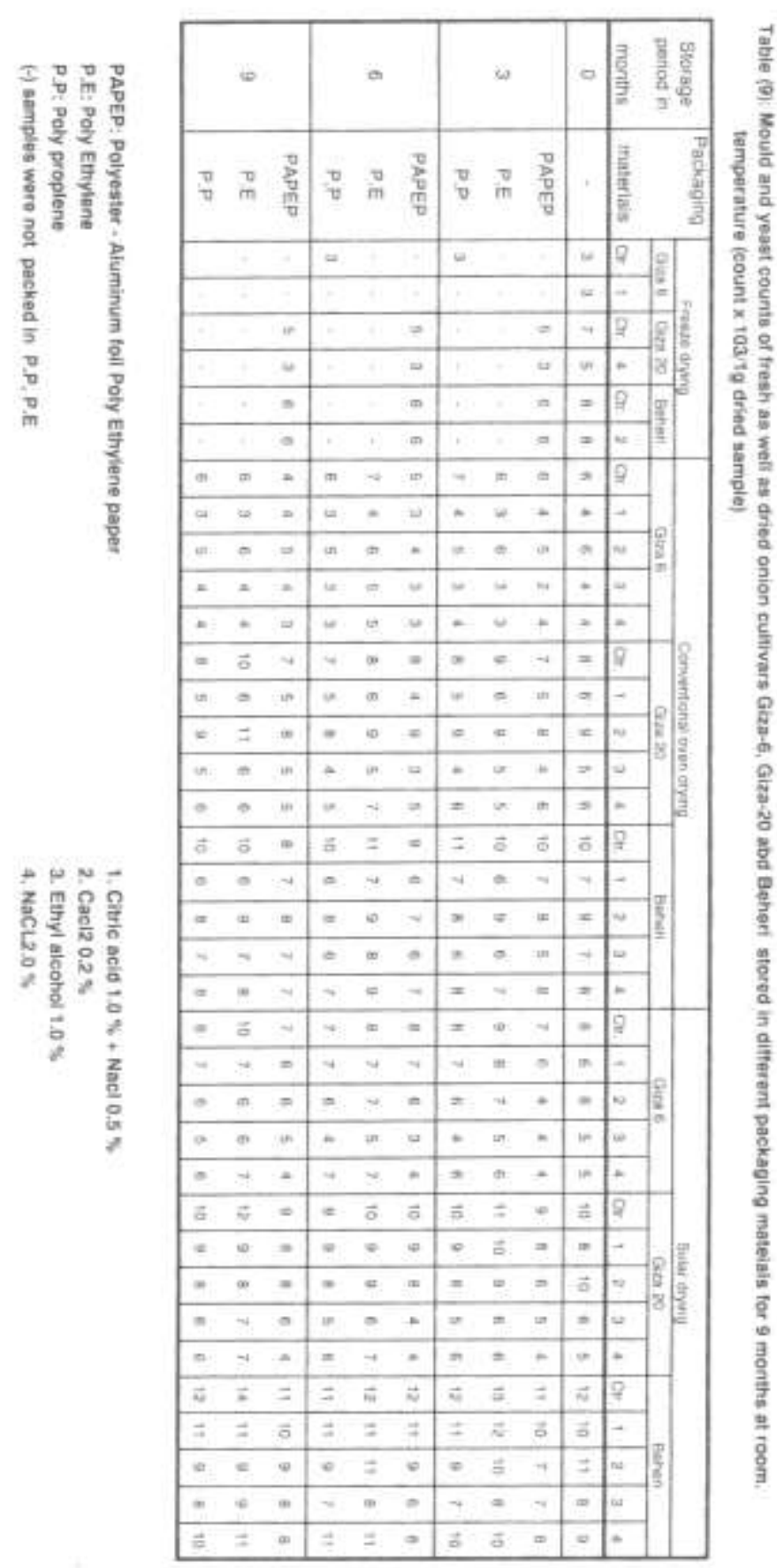


On the contrary, drying led to sharp decrease in the mould and yeast counts.

Concerning the total yeast and mould counts, the results in Table (9) show that the three cultivars of fresh onion had $22 \times 10^{3}, 28 \times 10^{3}$ and $23 \times 10^{3}$ (mould and yeast/lg fresh sample) for onion "Giza 6", "Giza 20" and "Beheri", respectively. On the contrary, drying led to sharp decrease in the mould and yeast counts.

It could be seen from the results in Table (9) that the mould and yeast counts for sliced onion dried by solar-drying method were higher than the other two drying methods. The packaging material had little effect on the mould and yeast counts. In this concern, samples packed into P.E. packaging material and slightly higher counts of mould and yeast.

Results in Tables (8-9) reveal also that, storage of sliced onions for 9 months in different packaging materials had almost the same counts of mould and yeast. These results are in agreement with those obtained by Frazier and Westhoff (1978) and Saleh and EL-Sherbieny (1994) who reported that dried vegetables had lower counts of mould and yeast than the fresh ones. However, the decrement in the counts was not sharp because the sliced onion was not blanched before drying.

\section{REFERENCES}

Adam E., Muhlbauer W., Esper A., Wolf W. and Spies W. (2000). Quality changes of onion (Allium cepa L.) as affected by the drying process. Die Nahrung. 44(1), 32-37.

A.O.A.C (1990). Official Methods of Analysis of Association Official Analytical Chemists $13^{\text {th }}$ Ed.Association of Official Analytical Chemists, Arlington Virginia ,USA.

Banwart G.J (1979). "Basic Food Microbiology," AVI publish company. INC. Westport, Connecticut. USA, 546-641.

Bolliger S., Casella M and Teuber M. (1994). Comparative impedance evaluation of the microbial load of different food stuffs, Lebensmittel- Wissenschart-Und-technologic, 27 (2) 177-184.

Da-Mota, Y.M and Palau E. (1999). Acoustic drying of onion. Drying Technology, 17 (4-5), 855867.

Firstenberg R, Mannheim C.A. and Cohen A. (1974). Microbial quality of dehydrated onions. J. Food Sci. 39, 685-688.

Frazier W.C. and Westhoff D.C. (1978). "Food Microbiology" Third Edition, Tata Mc GrawHill Publishing Co. Ltd., New Delhi., 143-153.

Hegazy N.A., Fadel Hoda H. M. and Ramadan A.A (1994). Effect of dehydration on some chemical constituents of onion. Egypt. J. Food Sci., No. 3, P. 369-379.

Ibarz A, Pagan J. and Garza S. (2000) Kinetic models of non-enzymatic browning in apple puree. J. of the Science of Food and Agriculture, 80, 1162 - 1168.

Jackson M.I. (1958). Soil Chemical Analysis Contable, Co. LTD, London, England, 498 pp.

Johan T.R. and Lovis J. (1980). Elementary Food Science Second Edition, AVI Publishing Company INC, Westport, Connecticut. USA, p. $113-121,168-170$.

Julseth R.M. and Deible R.H. (1974). Microbial profile of selected spices and herbs at import. J. Milk Food Technol., 37 (8) : 414.

Kaymak - Ertekin F. and Gedik A. (2005). Kinetic modeling of quality deterioration in onions during drying and storage. J. of Food Engineering 68, 443-453.

Krokida M. K. and Maroulis Z. B (1999). Effect of microwave drying on some quality properties of dehydrated products. Drying Technology 17(3), $449-466$.

Lancaster J.E. and Boland M.J. (1990). Flavor Biochemistry In: H.D. Robinowith and J.I. Brewster (eds.) Onion and Allied Crops, Vol. III. CRC Press. Boca Raton, Fla.

Maini S-B, Brijesh D. and Anand J.C. (1984). Storage behavior and drying characteristics of commercial cultivars of onion. Journal of Food Sci. and Technology India 21 (6) 417 - 419.

Mazza G. and Le-Maguer M. (1980). Flavour retention during dehydration of onion (Allium серa L.). Inp Linko, Y. Malkki, J. Olkku, and J. LKarinkari (eds) Food Process Engineering (vol.1, p. 399-406). London: Academic Press

Mesbah M. K. and Abu El-Ela S.H. (1991). Onion: A botanical wonder Bull. Fac. Pharm., Cairo Univ., 29 (3) : 33.

Park W.P. and Lee D.S (1994). Effect of chlorine treatment on cut water cress and onion. Journal of Food Quality (18) 415-424.

Peleg Y., Mannheim C.H. and Perk Z. (1970). Changes in quality of dehydrated Kibbled onions during storage. J.Food Sci. 35, 513.

Powar V.N, Singh Ni, Devs Dn., Kulkami Dn and Ingle E. (1988). Solar drying of white onion flakes.Indian-Food Packer, 42. (1):15-26.

Proudlove R.K.(1989) The Science and Technology of Foods ( $2^{\text {nd }}$ ed.). London: Forbcs Publications 1td. 247 pp.

Ranganna S. (1979). Manual of Analysis Fruit and Vegetable Products. Tata Mc Graw Hill, Publishing Company Limited, New Delhi. P. 150-161.

Rania B.L., Teotia M.A., Prothi J.S., Klara C.L., Singh S. and Nard Port K.S. (1988). Studies 
on the evaluation of some new onion cultivars for their suitability for dehydration. Indian Food Packer, 42. 7.

Saleh Y.G. and El-Sherbieny M. (1994). Chemical and microbiological studies on dehydrated onion varities. Egypt J. Apple. Sci., 9 (1) 620637.

Samaniego C.M., Boag L.F. and Robertson G.L. (1991). Kinetics of quality deterioration in dried onion and green beans as a function of temperature and water activity. Lebensm. Wiss. U.Technol., 24,53.

Schimmer S. and Weston W.J. (1961) Enzymatic development of pyruvic acid in onion as a measure of pungency. J. Agr. Food Chem. 9:301.

Sharma P.k. and Nath N. (1991). Sorption isotherm and storage characteristics of dehydrated rings of onion varieties. Lebensm. Wiss. Technol 24, 535 - 537.

Sharma P.K. and Niranvk N. (1991). Dehydration characteristics of ten onion cultivars- J. Fd Sci. Technol., 28 (6) 348-351.

Shekib A. Laila, Adel Y.S. and El-Tabey S. (1986). The effect of dehydration on pyruvic acid released from Egyptian onion. Alex J. Agric Res. 31 (1): 167-172.

Smogyi M. (1952). Notes on sugar determination. J. Biol. Chem. 195: 19-23

Wall M.M. and Corgan J.N. (1992). Relationship between pyruvate analysis and flavor perception for onion pungency determination. Hort. Sci. 27 (9), $1029-1030$.

Yamaguchi M., Parr A.R. and Morris L. (1982). Effect of storage temperature on keeping quality and composition of onion bulls and on subsequent darkening of dehydrated flakes. Pro. Amer. Soc. Hort. Sci. 80, 321.

Youssef A.M., Bou Enen Osman S.A. and Hewedy F.M. (1981). Chemical analysis of Egyptian onion and garlic. Research Bulletin 1468: 1., Fac. Agric., Ain Shams Univ.

\section{دراسات كيموفيزيائية وميكروبيولوجيةتعلى بعض أصناف البصل المصرية

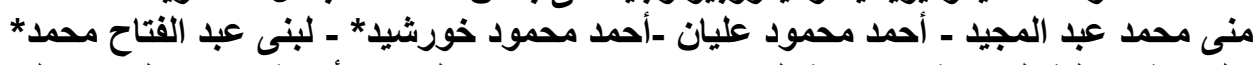

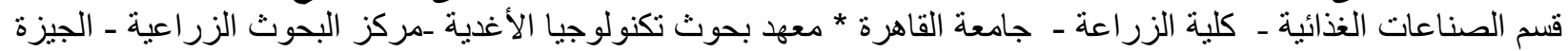

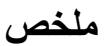

تمت الدر اسة على ثلاثة أصناف من البصل (جيزة 6، جيزة 20، بحيري) والمزروعة محلياً ، إشتملت على بعض

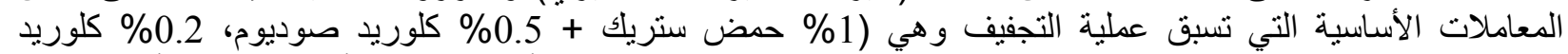

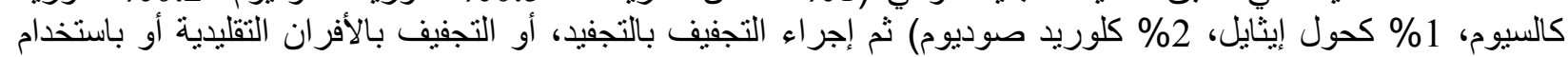

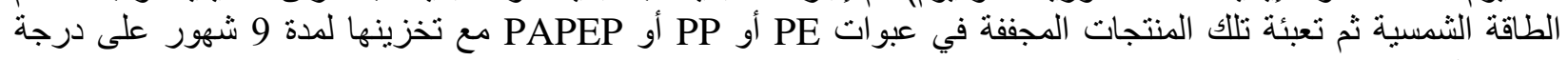

أوضحت الغرفة النتائج أن الرطوبة في البصل الطازج كانت 81,1، 82.8، 84.9\% لأصناف جيزة 6، جيزة 20، بحيري حرارة الغرفة.

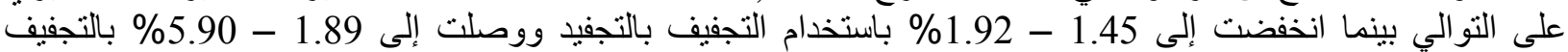

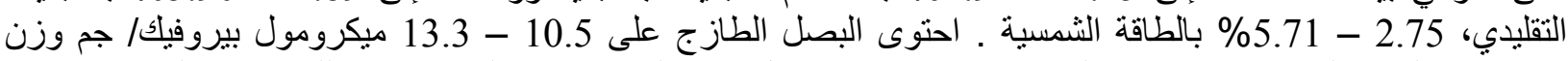

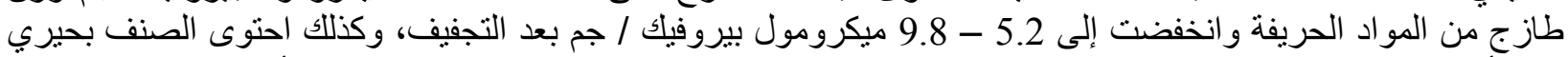

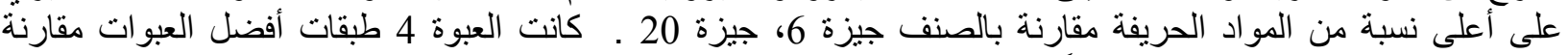

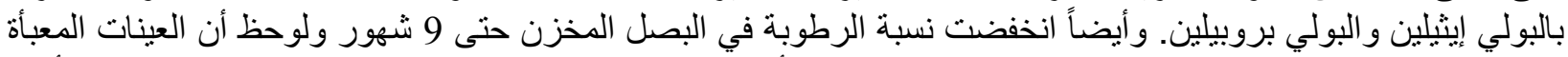

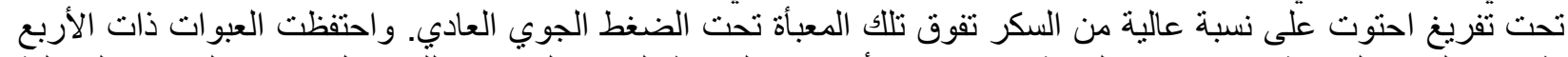

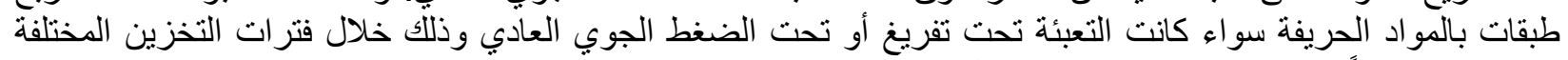

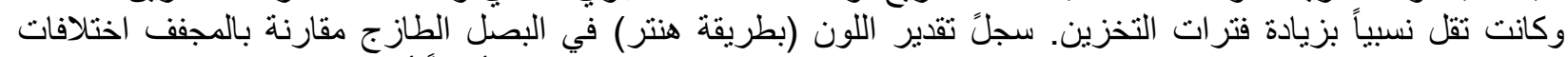

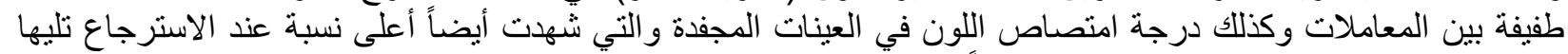

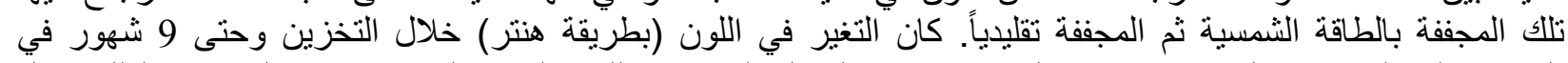

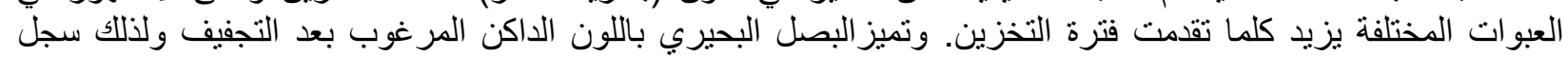

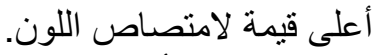

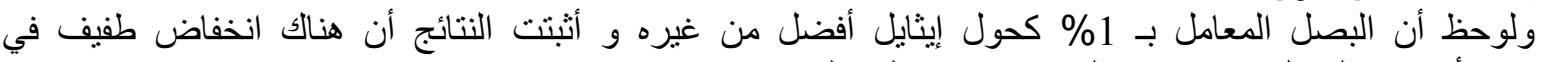

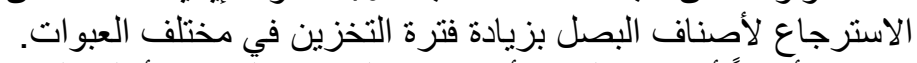

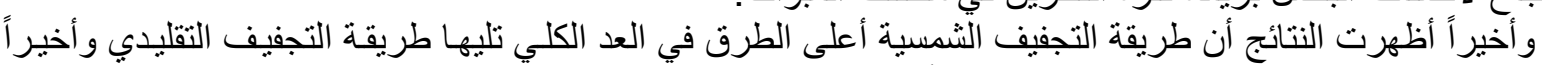

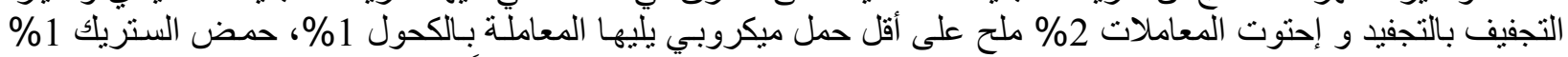

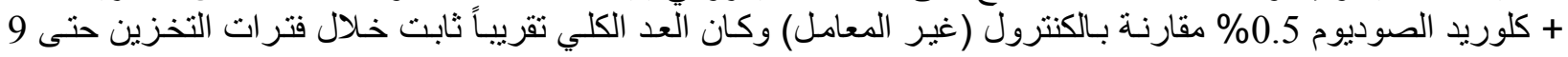
شهور في العبوات المختلفة. المجلة العلمية لكلية الزر اعة - جامعة القاهرة - المجلد (59) العدد الأول (يناير 2008):24-39. 